Published in final edited form as:

J Immunol. 2017 May 15; 198(10): 3869-3877. doi:10.4049/jimmunol.1602158.

\title{
RGC-32 Promotes Th17 Cell Differentiation and Enhances Experimental Autoimmune Encephalomyelitis
}

\author{
Violeta Rus ${ }^{\star}{ }^{\dagger}$, , Vinh Nguyen ${ }^{\star}, \dagger$, Alexandru Tatomir ${ }^{\dagger}, \ddagger$, Jason R. Lees ${ }^{\S}$, Armugam P. \\ Mekala $^{\dagger, \ddagger}$, Dallas Boodhoo ${ }^{\dagger,}$, , Cosmin A. Tegla ${ }^{\dagger,}$, , Irina G. Luzina ${ }^{*}$, , Paul A. Antony $\llbracket$, \\ Cornelia D. Cudrici", Tudor C. Badea ${ }^{\#}$, and Horea G. Rus ${ }^{\dagger, \ddagger}$ \\ * Division of Rheumatology and Clinical Immunology, Department of Medicine, University of \\ Maryland School of Medicine, Baltimore, MD 21201 \\ † Research Service, Veteran Affairs Medical Center, Baltimore, MD 21201 \\ ‡ Department of Neurology, University of Maryland School of Medicine, Baltimore, MD 21201; \\ $\S$ Department of Medicine, Uniformed Services University of the Health Sciences, Bethesda, MD \\ 20814; \\ I Department of Pathology, University of Maryland School of Medicine, Baltimore, MD 21201; \\ II National Institute of Arthritis and Musculoskeletal and Skin Diseases, National Institutes of \\ Health, Bethesda, MD 20892; \\ \# Retinal Circuit Development and Genetics Unit, Neurobiology Neurodegeneration and Repair \\ Laboratory, National Eye Institute, National Institutes of Health, Bethesda, MD 20892
}

\section{Abstract}

Th17 cells play a critical role in autoimmune diseases, including multiple sclerosis and its animal model, experimental autoimmune encephalomyelitis. Response gene to complement (RGC)-32 is a cell cycle regulator and a downstream target of TGF- $\beta$ that mediates its profibrotic activity. In this study, we report that RGC-32 is preferentially upregulated during Th17 cell differentiation. RGC-32-/- mice have normal Th1, Th2, and regulatory T cell differentiation but show defective Th17 differentiation in vitro. The impaired Th17 differentiation is associated with defects in IFN regulatory factor 4, B cell-activating transcription factor, retinoic acid-related orphan receptor $\gamma \mathrm{t}$, and SMAD2 activation. In vivo, $\mathrm{RGC}-32^{-/-}$mice display an attenuated experimental autoimmune encephalomyelitis phenotype accompanied by decreased CNS inflammation and reduced frequency of IL-17- and GM-CSF-producing CD4 ${ }^{+} \mathrm{T}$ cells. Collectively, our results identify RGC-32 as a novel regulator of Th17 cell differentiation in vitro and in vivo and suggest that RGC-32 is a potential therapeutic target in multiple sclerosis and other Th17-mediated autoimmune diseases.

Address correspondence and reprint requests to Dr. Violeta Rus, University of Maryland School of Medicine, MSTF Building, Room 8-34, 10 South Pine Street, Baltimore, MD 21201. address: vrus@umaryland.edu.

Disclosures

The authors have no financial conflicts of interest. 
The response gene to complement (RGC)-32 is a cell cycle regulator expressed in normal tissues, including brain, kidney, spleen, thymus, multiple tumors, and in a variety of cell lines (1-5). RGC-32 is localized in the cytoplasm and translocates to the nucleus upon upregulation by complement activation, growth factors, and cytokines $(6,7)$. A membrane associated form was also described in macrophages (3).

Depending on the cell type and physiological or pathological conditions, RGC-32 can stimulate cell growth through increased $\mathrm{p} 34^{\mathrm{CDC} 2}$ kinase activity and Akt phosphorylation or suppress it via arrest in mitotic progression $(1,6,8,9)$. Initially identified in rat oligodendrocytes in response to the sublytic C5b-9 complex, RGC-32 is induced by TGF- $\beta$ in fibroblasts, astrocytes, and human renal proximal tubular cells $(5,10,11)$. In these cells, RGC-32 mediates TGF- $\beta$-dependent profibrotic pathways, including epithelialmesenchymal transition, fibroblast activation, and extracellular matrix production of collagen.

Few studies have evaluated the expression and function of RGC-32 in the immune system. RGC-32 mRNA and protein expression was detected in primary and secondary lymphoid organs of normal mice $(4,12)$. Among innate immune cells, murine macrophages express a membrane-associated form that enhances phagocytosis (3). In adaptive immune cells, we recently reported that RGC-32 is upregulated in TCR-stimulated mouse $\mathrm{CD} 4^{+} \mathrm{T}$ cells (12). RGC-32-deficient $\mathrm{CD}^{+}{ }^{+} \mathrm{T}$ cells exhibit enhanced proliferation, IL-2 production, and Akt phosphorylation as compared with RGC-32-sufficient $\mathrm{CD} 4^{+} \mathrm{T}$ cells, suggesting a downregulatory role of RGC-32 under Th0 conditions. In contrast, in human B cells, RGC-32 exerts a stimulatory role and promotes the survival and proliferation of EBV immortalized B cells (13).

In human diseases, we have reported increased expression of RGC-32 protein in macrophages, $\mathrm{T}$ cells, and astrocytes in the brain of patients with multiple sclerosis (MS) and in the colonic mucosa of patients with inflammatory bowel disease $(5,14)$. A large body of evidence supports the role of proinflammatory Th17 cells in the pathogenesis of MS and other autoimmune diseases (15-21). As TGF- $\beta$ plays a critical role in promoting Th17mediated immune responses, in this study we examined whether RGC-32, as a downstream target of TGF- $\beta$, plays a role in the differentiation of murine Th17 cells in vitro and in the Th17-mediated response in the experimental autoimmune encephalomyelitis (EAE) model in vivo. Our results show that RGC-32 expression is preferentially upregulated in Th17 cells and that lack of RGC-32 results in impaired Th17 differentiation in vitro and an attenuated EAE phenotype in vivo. The defect in Th17 differentiation is associated with alterations in multiple transcription factors in the Th17 cell differentiation network, including IFN regulatory factor (IRF)4, B cell-activating transcription factor (BATF), retinoic acid-related orphan receptor (ROR) $\delta$ t, and SMAD2 activation. Thus, our results establish, to our knowledge for the first time, that RGC-32 is an important mediator that promotes Th17 differentiation and autoimmunity and suggest that RGC-32 is a potential therapeutic target in MS and other Th17-mediated diseases. 


\section{Materials and Methods}

Mice

All mice were on C57BL/6 background, used at 6-12 wk of age, and housed in specific pathogen-free conditions. RGC-32-/- mice have been described previously (12). Wild-type (WT) C57BL/6 mice littermates were used as controls. Rag $1^{-/-}$mice were purchased from The Jackson Laboratory. All procedures were approved by the University of Maryland School of Medicine Office of Animal Welfare Assurance.

\section{Abs and flow cytometry}

Spleen cells were first incubated with anti-murine FcgRII/III mAb (2.4G2) for $10 \mathrm{~min}$ and then stained with saturating concentrations of Alexa Fluor 488-conjugated, allophycocyanin-conjugated, biotin-conjugated, PEconjugated, FITC-conjugated, PE/Cy5conjugated, or PE/Cy7-conjugated mAbs against IL-17, IL-4, IFN- $\gamma$ (BD Biosciences), CD4, glucocorticoidinduced TNFR (BioLegend, San Diego, CA), Foxp3, CTLA4, RORס, GMCSF, and program death-1 (eBioscience, San Diego, CA). Biotinylated primary mAbs were detected using either streptavidin-allophycocyanin (BioLegend), streptavidin-FITC, streptavidin-PE, or streptavidin-PE/Cy5 (BD Biosciences, San Jose, CA). Primary rabbit anti-mouse RGC-32 Ab (Sigma-Aldrich, St. Louis, MO) was detected using secondary FITC-labeled goat anti-rabbit Ab (Santa Cruz Biotechnology, Dallas, TX). For intracellular cytokine staining, cells were stimulated with $50 \mathrm{ng} / \mathrm{ml} \mathrm{PMA} \mathrm{(Sigma-Aldrich)} \mathrm{and} 1 \mu \mathrm{g} / \mathrm{ml}$ ionomycin (Sigma-Aldrich) for $4 \mathrm{~h}$, and GolgiPlug was added for the last $2 \mathrm{~h}$ (BD Biosciences); cells were then stained for CD4 and intracellular cytokines as previously described (22). Multicolor flow cytometric analyses were performed using an Accuri C6 and LSR II flow cytometer (BDBiosciences).

\section{$\mathrm{CD}^{+} \mathrm{T}$ cell preparation and differentiation in vitro}

Spleen cells were excised from mice and single-cell suspensions of splenocytes were prepared in RPMI 1640 by teasing the organ through a sterile nylon mesh. Naive $\mathrm{CD} 4^{+} \mathrm{T}$ cells were purified using an EasySep mouse naive $\mathrm{CD}^{+} \mathrm{T}$ cell isolation kit (Stemcell Technologies, Vancouver, BC, Canada) and cultured with plate-bound anti-CD3 $(5 \mu \mathrm{g} / \mathrm{ml}$; Bio X Cell), anti-CD28 (5 $\mu \mathrm{g} / \mathrm{ml}$; Bio X Cell), and cytokines used alone, including IL-12 (R\&D Systems), IFN- $\gamma$ (R\&D Systems), IL-1 (R\&D Systems), IL-4 (R\&D Systems), IL-6 (Cell Signaling Technology), IL-23 (eBioscience), and TGF- $\beta$ (Invitrogen), or in combination with Abs (Bio X Cell) for Th17-promoting (2.5 ng/ml TGF- $\beta, 20 \mathrm{ng} / \mathrm{ml} \mathrm{IL-6,}$ $10 \mu \mathrm{g} / \mathrm{ml}$ anti-IFN- $\gamma, 10 \mu \mathrm{g} / \mathrm{ml}$ anti-IL-4, $10 \mu \mathrm{g} / \mathrm{ml}$ anti-IL-2), Th1-promoting $(10 \mathrm{ng} / \mathrm{ml}$ IL-12, $5 \mu \mathrm{g} / \mathrm{ml}$ anti-IL-4), Th2-promoting ( $10 \mathrm{ng} / \mathrm{ml} \mathrm{IL-4,} 5 \mu \mathrm{g} / \mathrm{ml}$ anti-IFN- $\gamma$ ), or regulatory $\mathrm{T}$ cell (Treg)-promoting ( $5 \mathrm{ng} / \mathrm{ml}$ TGF- $\beta, 5 \mu \mathrm{g} / \mathrm{ml}$ anti-IFN- $\gamma, 5 \mu \mathrm{g} / \mathrm{ml}$ anti-IL-4) conditions. In some experiments, naive $\mathrm{CD}^{+} \mathrm{T}$ cells were cultured in Th17-promoting conditions and IL-21 (20 ng/ml; eBioscience) or IL-23 (50 ng/ml) was added to cultures after $24 \mathrm{~h}$. Cells were harvested after $48 \mathrm{~h}$ for real-time PCR analysis and after $72 \mathrm{~h}$ for cytokine expression by flow cytometry as previously described (23). 


\section{Cytokine ELISA}

Splenic naive $\mathrm{CD}^{+} \mathrm{T}$ cells were stimulated as described above. After $72 \mathrm{~h}$, IFN- $\gamma$, IL-4, and IL-17A were measured in supernatants by ELISA as previously described (22).

\section{Proliferation assay}

CFSE-labeled naive CD4 cells were cultured under Th17 conditions, and cell proliferation was assessed after $72 \mathrm{~h}$ as previously described (22).

Splenocyte suspensions were generated from myelin oligodendrocyte glycoprotein $(\mathrm{MOG})_{35-55^{-} \text {immunized WT and RGC-32 }}{ }^{-/}$mice. On day 10 after immunization, splenocytes from individual mice depleted of RBCs were cultured $\left(5 \times 310^{5}\right.$ cells per well $)$ in 96-well microplates in $200 \mathrm{ml}$ of IMDM with and without $25 \mu \mathrm{g} / \mathrm{ml} \mathrm{MOG}_{35-55}$ peptide. $\left[{ }^{3} \mathrm{H}\right]$ thymidine was added during the last $18 \mathrm{~h}$ of a 72 -h culture. The cells were then collected and counted with a beta counter.

\section{In vitro $\mathrm{T}$ cell suppression assays}

Naive $\mathrm{CD} 4{ }^{+} \mathrm{T}$ cells were purified from WT and RGC-32-/- spleen cells using an EasySep mouse naive CD4 T cell isolation kit (Stemcell Technologies). Cells were then cultured under Treg differentiating conditions for $72 \mathrm{~h}$. Treg differentiation was tested by induction of Foxp3 by FACS analysis. CD ${ }^{+} \mathrm{CD} 25^{+}$Tregs were purified using a mouse Treg isolation kit II (Stemcell Technologies). For the suppression assay, $5 \times 10^{4}$ purified $\mathrm{CD} 4^{+} \mathrm{CD} 25^{+}$Tregs were cultured in triplicate with $5 \times 10^{4}$ or $2.5 \times 10^{4}$ purified $\mathrm{CD} 4^{+} \mathrm{CD} 25^{2} \mathrm{~T}$ effectors $(\mathrm{T}$ responder) and $1 \mu \mathrm{g} / \mathrm{ml}$ anti-CD3 $\mathrm{mAb}$ in a 96-well round-bottom plate. T cell-depleted splenocytes from C57BL/6 mice $\left(4 \times 10^{5}\right)$ irradiated with $3000 \mathrm{~Gy}$ were used as APCs. Proliferation of the T responder cells was determined by $\left[{ }^{3} \mathrm{H}\right]$ thymidine incorporation. Percentage suppression of $\mathrm{T}$ responder proliferation was calculated using the formula: $100 \times$ [( $\mathrm{cpm}$ of $\mathrm{T}$ responder cells alone $2 \mathrm{cpm}$ of $\mathrm{T}$ responder cells cocultured with Tregs)/cpm of $\mathrm{T}$ responder cells alone].

\section{Isolation of lamina propria lymphocytes}

Mice were killed and intestines removed and placed in ice-cold PBS. After removal of mesenteric fat tissue, Peyer's patches were excised, and the intestine was opened longitudinally, thoroughly washed in ice-cold PBS, and cut into $1.5-\mathrm{cm}$ pieces. Epithelial cells were removed by sequential shaking (twice) in $5 \mathrm{mM}$ EDTA in HBSS. The remaining tissue was washed in HBSS, cut into $1-\mathrm{mm}^{2}$ pieces, and digested twice at $37^{\circ} \mathrm{C}$ in $\mathrm{T}$ cell media containing $1 \mu \mathrm{g} / \mathrm{ml}$ collagenase D (Roche, Indianapolis, IN) and $40 \mu \mathrm{g} / \mathrm{ml}$ DNase I (Sigma-Aldrich). Lamina propria lymphocytes were isolated by a $40 / 80 \%$ Percoll gradient. Isolated cells were stimulated for $4 \mathrm{~h}$ with PMA/ionomycin and GolgiPlug followed by intracellular cytokine staining as described (23).

\section{RNA isolation and quantitative real-time RT-PCR analysis}

Total RNA isolation, quantitation, and reverse transcription were performed as described (24). 18S rRNA was used as an internal control. Quantitative real-time PCR was performed using SYBR Green master mix (Roche). Results for each gene were expressed as fold 
increase over the expression in control naive $\mathrm{CD} 4^{+} \mathrm{T}$ cells. Primers for IL-17F, IL-23R, and Rorc were purchased from SABiosciences (Frederick, MD). Primer sequences for IL-22, IRF4, and BATF are listed in Supplemental Table I.

\section{Immunoblotting}

At the indicated time points, naive $\mathrm{CD} 4^{+} \mathrm{T}$ cells cultured under Th17 conditions were harvested in RIPA lysis buffer as previously described (25). Thirty micrograms of protein lysate was assayed by immunoblotting using primary Abs for phosphorylated STAT3, SMAD2, and SMAD3 (Cell Signaling Technology, Danvers, MA) and goat anti-rabbit IgGHRP secondary Ab (Santa Cruz Biotechnology) as previously described (25). Membranes were stripped and reprobed for the respective total protein content or b-actin to verify loading evenness.

\section{Induction and evaluation of EAE}

Female mice (8-10 wk old) were injected s.c. in two locations in the dorsal flank with an emulsion containing $200 \mu \mathrm{g}$ of $\mathrm{MOG}_{35-55}$ (Anaspec, Fremont, CA) and CFA (Difco, Detroit, MI) as previously described (26, 27). Pertussis toxin (400 ng; List Biological Laboratories, Campbell, CA) was administered i.p. on days 0 and 2. CD4 ${ }^{+} \mathrm{T}$ cell-reconstituted $\operatorname{Rag} 1^{-/-}$ mice were immunized with $150 \mu \mathrm{g}$ of MOG peptide emulsified in CFA at day 0 and day 7 as previously described (28). Pertussis toxin was given i.p. at day 1 and day 8 (500 ng per injection). Mice were monitored daily and the disease was scored on a scale of $0-5$ as follows: 1 , limp tail; 2 , hindlimb paresis; 3 , hindlimb paralysis; 4 , tetraplegia; 5, moribund $(27,29)$.

\section{Isolation of CNS mononuclear cells}

At the indicated time points, the brain and spinal cord were collected from perfused mice and mononuclear cells were prepared by Percoll gradient centrifugation. The proportion and total numbers of $\mathrm{CD}^{+} \mathrm{T}$ cells were determined. For cytokine profiles, cells were restimulated with PMA and ionomycin for $4 \mathrm{~h}$ in the presence of brefeldin and subjected to flow cytometry analysis.

\section{Histological analysis}

Spinal cords from EAE mice were dissected on day 14 and stained as described previously with H\&E and Luxol fast blue $(27,29)$.

\section{$\mathrm{CD}^{+} \mathrm{T}$ cell transfer}

$\mathrm{CD} 4^{+} \mathrm{T}$ cells were prepared from the spleen and inguinal lymph nodes of WT mice using a $\mathrm{CD}^{+} \mathrm{T}$ cell isolation kit (Stemcell Technologies; purity .97\%). $\mathrm{CD}^{+} \mathrm{T}$ cells were injected i.v. $\left(2 \times 10^{7}\right.$ cells per mouse $)$ into WT or RGC- $32^{-/-}$mice. Five days later, the recipient mice were subjected to EAE induction. Rag $1^{-/-}$mice were reconstituted with $7 \times 10^{6} \mathrm{CD}^{+} \mathrm{T}$ cells from C57BL/6 or RGC-32 ${ }^{-1}$ mice. One day later, EAE was induced in the recipient mice. 


\section{Statistical analysis}

Statistical analyses were performed in Prism 6 (GraphPad Software). For comparison between two groups, data were analyzed with the Student $t$ test or Wilcoxon rank-sum test for nonparametric. For three or more groups data were analyzed with one-way ANOVA.

\section{Results}

\section{RGC-32 expression is induced preferentially during Th17 differentiation}

Our previous study showed that RGC-32 mRNA expression is upregulated in mouse $\mathrm{CD}^{+} \mathrm{T}$ cells under TCR stimulation conditions (12). As RGC-32 is upregulated by TGF- $\beta$ in a number of cell lines, we determined whether it is also induced by TGF- $\beta$ or other cytokines in mouse $\mathrm{CD} 4^{+} \mathrm{T}$ cells. TGF- $\beta$ induced the highest upregulation of RGC-32 mRNA expression in WT CD4 ${ }^{+} \mathrm{T}$ cells, followed in magnitude by other Th17-related cytokines such as IL-6, IL-23, and IL-1b, although these did not reach statistical significance (Fig. 1A). IFN- $\gamma$, IL-12, and IL-4 modestly upregulated RGC-32 transcripts. We next determined whether RGC-32 is upregulated in the TGF- $\beta$-dependent Th cell subsets, Th17 cells, and Tregs in comparison with Th0, Th1, and Th2 subsets. At both the mRNA and protein levels, RGC-32 upregulation was more robust under Th17 versus Treg polarizing conditions (Fig. 1B, 1C). To a lesser extent, RGC-32 mRNA was upregulated in Th0 and Th1 but not in Th2 conditions. These results indicate that RGC-32 is preferentially induced during Th17 polarization.

\section{RGC-32 is necessary for Th17 but not Th1, Th2, or Treg differentiation}

To determine whether RGC-32 plays a role in the differentiation of mouse Th17 cells, we isolated naive $\mathrm{CD}^{+}{ }^{+} \mathrm{T}$ cells from WT or RGC-32-/- mice and stimulated them under Th17 polarizing conditions. $\mathrm{CD} 4^{+} \mathrm{T}$ cells from $\mathrm{RGC}-32^{-/-}$mice failed to polarize normally to the Th17 lineage, as they exhibit a significant reduction in the proportion of $\mathrm{IL}-17 \mathrm{~A}^{+} \mathrm{CD} 4^{+} \mathrm{T}$ cells (Fig. 1D, 1E), the amount of secreted IL-17A (Fig. 1F), and the level of IL-17A transcripts (Fig. 1G). This defect extends to other Th17 signature genes such as IL-17F, IL-21, IL-22, and IL-23R that showed similarly impaired transcript upregulation in RGC- $-32^{-/-}$versus WT CD4 ${ }^{+}$T cells (Fig. $1 \mathrm{H}$ ).

TGF- $\beta$ plays a critical role in the differentiation of Th17 cells both in vitro and in vivo (30). To determine whether RGC-32 deficiency impaired Th17 development in vivo, we assessed the expression of IL-17A in the intestinal tissue, a site where $\mathrm{IL}-17^{+} \mathrm{T}$ cells are normally enriched (31). In agreement with our in vitro differentiation data, $21.261 .9 \%$ of lamina propria $\mathrm{CD} 4^{+} \mathrm{T}$ cells from RGC-32 $2^{+/+}$mice expressed IL-17A (Fig. 2A, 2C), whereas in RGC-32 $2^{-/-}$mice, the proportion and absolute number of $\mathrm{IL}-17^{+}$cells were reduced $\sim 2$-fold (Fig. 2). These data suggest that RGC-32 $2^{-/}$may play an important role in the generation of Th17 cells in vivo.

The impaired in vitro differentiation was specific for the Th17 lineage, as the proportion of IFN- $\gamma^{+}$(Fig. 3A) and the amount of secreted IFN- $\gamma$ (Fig. 3B) did not differ between WT and $\mathrm{RGC}-32^{-/-} \mathrm{CD} 4^{+} \mathrm{T}$ cells under Th1 conditions. Under Th2 conditions, the percentage of IL- $4^{+} \mathrm{CD} 4^{+} \mathrm{T}$ cells (Fig. 3C) and the amount of secreted IL-4 (Fig. 3D) were comparable 
in WT and RGC-32 ${ }^{-/-} \mathrm{CD} 4^{+} \mathrm{T}$ cells. Similarly, the proportion of in vitro- differentiated Tregs (induced Tregs [iTregs]) was comparable in WT and RGC-32 $2^{-/}$mice (Fig. 3E). Furthermore, iTregs from RGC-32 $2^{-1-}$ mice displayed similar expression of glucocorticoidinduced TNFR, CTLA-4, and program death-1, markers known to modulate Treg development and function (32-34) (Supplemental Fig. 1). Functionally, purified iTregs from RGC-32 ${ }^{-1}$ mice suppressed the proliferation of $\mathrm{T}$ responder cells to the same extent as did iTregs from WT mice (Fig. 3F), suggesting that lack of RGC-32 does not affect the number or function of iTregs.

\section{Impaired Th17 differentiation in RGC-32-/- CD4+ $T$ cells is not due to altered IL-2/IL-2R expression or proliferative response}

Our previous study showed that under Th0 conditions, RGC- $-32^{-/-} \mathrm{CD} 4^{+} \mathrm{T}$ cells exhibit increased IL-2 production and proliferation (12). As IL-2 signaling inhibits Th17 differentiation (35-37), we first examined whether increased production or responsiveness to IL-2 might account for the impaired Th17 differentiation of RGC- $32^{-/-} \mathrm{CD} 4^{+} \mathrm{T}$ cells. However, under Th17 conditions, we did not observe a significant difference in the level of intracellular or secreted IL-2 between WT and RGC-32-/- CD4+ $\mathrm{T}$ cells (Fig. 4A, 4B). Additionally, expression of the high-affinity IL-2 receptor chain CD25 was comparable between RGC-32-sufficient and -deficient CD4 ${ }^{+} \mathrm{T}$ cells, suggesting that IL-2 production and responsiveness to IL-2 do not account for the impaired Th17 differentiation of RGC-32 ${ }^{-/-}$CD4 ${ }^{+} \mathrm{T}$ cells (Fig. 4C). Furthermore, whereas neutralization of endogenous IL-2 markedly enhanced the proportion of $\mathrm{IL}-17^{+} \mathrm{CD} 4^{+} \mathrm{T}$ cells from both WT and RGC-32 $2^{-/}$ mice, it did not correct the impaired Th17 differentiation of RGC- $32^{-/-} \mathrm{IL}-17^{+} \mathrm{CD} 4^{+} \mathrm{T}$ cells (data not shown), suggesting that the defect was independent of endogenous IL-2. We next assessed whether the impaired differentiation of RGC- $32^{-/-} \mathrm{CD} 4^{+} \mathrm{T}$ cells under Th17 conditions is due to a general defect in the proliferation/expansion of $\mathrm{CD} 4^{+} \mathrm{T}$ cells. By CFSE dilution analysis, there was no difference in the extent of cell division between WT and RGC-32-/- CD4 $4^{+} \mathrm{IL}-17^{+}$cells (Fig. 4D). Furthermore, the absolute numbers of $\mathrm{CD} 4^{+} \mathrm{T}$ cells recovered after culture under Th17 conditions did not differ between WT and RGC- $32^{-/-} \mathrm{CD}^{+} \mathrm{T}$ cells, suggesting that the decreased proportion of RGC-32-/$\mathrm{CD} 4{ }^{+} \mathrm{IL}-17 \mathrm{~A}^{+} \mathrm{T}$ cells was not due to suppression of $\mathrm{T}$ cell proliferation. Thus, the effect of RGC-32 on Th17 differentiation is independent of its ability to regulate IL-2 production and proliferative responses under Th0 conditions.

\section{RGC-32 promotes Th17 cell differentiation throughTGF- $\beta$-dependent and -independent mechanisms}

Th17 differentiation requires the activation of a multifactorialtranscriptional complex that includes BATF, IRF4, STAT3, and themaster transcription factor ROR $\gamma \mathrm{t}$ (38-40). Consistent with theimpaired Th17 differentiation observed in vitro, the frequency of ROR $\gamma \mathrm{t}^{+} \mathrm{CD} 4^{+} \mathrm{T}$ cells and the mRNA expression of Rorc weresignificantly decreased in RGC-322/2 CD4 ${ }^{+} \mathrm{T}$ cells comparedwith WT controls (Fig. 5A-C). Similarly, mRNA expression ofBATF and IRF4 was also significantly decreased in RGC-322/2CD4+ T cells (Fig. 5D). In contrast, phosphorylated STAT3 wasinduced to similar levels within $15 \mathrm{~min}$ in both WTand RGC-322/2 CD4 ${ }^{+} \mathrm{T}$ cells and was sustained to comparable levels at 30 and60 min (Fig. 5E, $5 \mathrm{~F})$. 
Next, we assessed whether alterations in TGF- $\beta$ signaling contribute to the defective Th17 differentiation of RGC-32-/- CD4 ${ }^{+} \mathrm{T}$ cells. Under Th17 conditions, phosphorylated SMAD2 was induced to comparable levels at 15 and $30 \mathrm{~min}$ and was further increased at $60 \mathrm{~min}$ in WT but not in RGC-32-deficient CD4 ${ }^{+} \mathrm{T}$ cells (Fig. 5E, 5G). In contrast, SMAD3 phosphorylation was induced with similar kinetics and magnitude in WT and RGC-32-/$\mathrm{CD}^{+} \mathrm{T}$ cells at all time points (Fig. $5 \mathrm{E}, 5 \mathrm{H}$ ). Collectively, these results indicate that the impaired Th17 differentiation of RGC-32 ${ }^{-/} \mathrm{CD} 4^{+} \mathrm{T}$ cells is due to alterations in multiple transcription factors in the Th17 cell differentiation network.

Whereas TGF- $\beta$ and IL- 6 are critical for the initiation of Th17 cell differentiation, IL- 21 and IL-23 are required for the stabilization and maintenance of Th17 cells $(41,42)$. As IL-21 and IL-23R mRNA were reduced in RGC-32 ${ }^{-/-}$CD $4^{+} \mathrm{T}$ cells activated under Th17 conditions (Fig. 1H), we assessed whether supplementation with IL-23 or IL-21 can rescue IL-17 production in these cells. As seen in Fig. 6, exogenous IL-21 and IL-23 added after $24 \mathrm{~h}$ of culture did not correct the defect in IL-17 production in RGC-32 ${ }^{-/-} \mathrm{CD} 4^{+} \mathrm{T}$ cells, albeit a trend for an increased percentage of IL-17-producing CD4 ${ }^{+} \mathrm{T}$ cells was noted. Although other factors could also contribute to RGC-32-dependent IL-17 production, these data suggest that RGC-32 expression is more important for the priming of Th17 cells than for the maintenance of the Th17 phenotype in vitro.

\section{RGC-32 deficiency attenuates EAE}

To evaluate the relevance of RGC-32 in an IL-17-dependent inflammatory condition, we induced EAE in WT and RGC-32-/- mice by immunization with $\mathrm{MOG}_{35-55}$ peptide emulsified in CFA. As seen in Fig. 7A, the timing of disease onset was similar in both groups of mice. However, RGC-32 ${ }^{-/}$mice developed significantly less severe disease at peak disease (Fig. 7A). The attenuated EAE phenotype was confirmed by histopathologic examination of the spinal cords that showed fewer inflammatory infiltrates and demyelination foci in RGC-32-/- mice than in WT EAE mice (Fig. 7B, 7C). Consistent with the in vitro data, the percentage and absolute number of $\mathrm{CD} 4^{+} \mathrm{IL}-17^{+}$cells were significantly lower in the CNS of RGC-32 $2^{-/}$EAE mice, confirming in vivo the role of RGC-32 in Th17 cell generation. The significant difference observed in the percentage and number of IL- $17^{+} \mathrm{IFN}-\gamma^{+} \mathrm{CD} 4^{+} \mathrm{T}$ cells (Fig. 7E,7F) is largely due to the reduction in $\mathrm{IL}-17^{+} \mathrm{CD} 4^{+}$cells, as the percentage and number of IFN- $\gamma^{+} \mathrm{CD} 4^{+} \mathrm{T}$ cells did not differ between WT and RGC-32-/- EAE mice. The number and percentage of Foxp $3^{+} \mathrm{CD} 4^{+} \mathrm{T}$ cells was similar in both groups, suggesting that the attenuated disease severity in RGC-32 ${ }^{-/-}$mice was not due to an increase in Tregs. Interestingly, the frequency and number of GM-CSF-producing $\mathrm{CD}^{+} \mathrm{T}$ cells, a subset with highly pathogenic potential (43, 44), were also significantly decreased in RGC-32-/- EAE mice (Fig. 7E, 7F). Collectively, these data implicate RGC-32 in the generation of two main encephalitogenic cytokines in autoimmune inflammation, IL-17 and GM-CSF.

Next, we assessed whether RGC-32 deficiency impairs the Ag-specific expansion of T cells in response to $\mathrm{MOG}_{35-55}$ peptide. Spleen cells from $\mathrm{MOG}_{35-55}$-immunized RGC-32-/mice proliferate to the same extent as do those from WT mice and even exhibit a trend for increased proliferation (Fig. 7G). These results demonstrate the ability of RGC-32-/- CD4 ${ }^{+}$ 
T cells to expand in response to MOG peptide, suggesting that an Agspecific proliferative abnormality in RGC-32- $2^{--} \mathrm{T}$ cells does not contribute to the attenuated EAE observed in these mice.

To determine whether the attenuated EAE in RGC- $32^{-/-}$mice resulted from a T cellmediated defect, we transferred WT CD4 ${ }^{+}$T cells into WT or RGC-32-/- mice before MOG immunization. Both WT and RGC-32 $2^{--}$mice receiving $\mathrm{CD} 4^{+} \mathrm{T}$ cells from WT mice developed EAE of similar severity (Fig. $7 \mathrm{H}$ ) accompanied by a comparable percentage and absolute number of CNS-infiltrating IL-17-producing CD4 ${ }^{+} \mathrm{T}$ cells (Fig. 7I, 7J). To further investigate the T cell-intrinsic nature of the Th17 defect observed in RGC-32-/- mice, we transferred total CD4 T cells from WT and RGC32-/- mice into RAG1-deficient animals and induced EAE. Mice receiving RGC- $32^{-/-} \mathrm{CD} 4^{+} \mathrm{T}$ cells exhibited reduced severity of disease compared with mice receiving WT CD4 ${ }^{+} \mathrm{T}$ cells (Fig. 7K). These data suggest that the attenuated EAE phenotype in RGC-32-/- mice is T cell mediated.

\section{Discussion}

Th17 cells play an important role in inflammation and autoimmunity. In this study, we demonstrate, to our knowledge for the first time, a novel role for RGC-32 in the differentiation of Th17 cells in vitro and in the generation of encephalitogenic Th17 cells

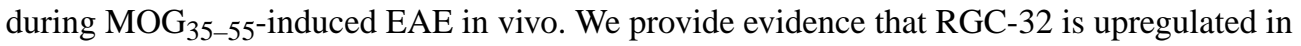
murine $\mathrm{CD} 4^{+} \mathrm{T}$ cells in response to TCR stimulation and several cytokines and is preferentially expressed under Th17 polarization conditions. RGC-32 deficiency led to impaired in vitro Th17 cell differentiation as demonstrated by lower percentages of IL-17producing $\mathrm{CD}^{+}$cells and decreased expression of IL-17 signature genes in RGC-32-/- as compared with WT mice. In agreement with the in vitro data, $\mathrm{CD} 4^{+} \mathrm{T}$ cells isolated from the gut of RGC-32-deficient mice exhibited fewer IL- $17^{+}-$secreting cells than did those obtained from control mice. Furthermore, RGC-32 deficiency decreased EAE clinical and histopathological severity, as well as the frequency of IL-17- and GM-CSF-producing cells in the CNS, supporting an important role for RGC-32 in the control of Th17 development in vivo.

Lack of RGC-32 impaired in vitro differentiation of Th17 cells without effects on Th1, Th2, and Treg lineages. In concordance with the in vitro data, T cells from the CNS of RGC-32-/EAE mice displayed similar percentages and absolute numbers of Foxp $3^{+}$and IFN- $\gamma^{+} \mathrm{CD}^{+}$ $\mathrm{T}$ cells but decreased numbers of IL-17- producing cells, supporting the predominant effect of RGC-32 in Th17 differentiation.

Although RGC-32 was first described as a cell cycle activator, depending on the cell type and conditions, it can either stimulate or suppress cell proliferation $(1,6,9)$. The observed decrease in the proportion of $\mathrm{IL}-17^{+}$cells in RGC-32-deficient $\mathrm{CD} 4^{+} \mathrm{T}$ cells in vitro or in the CNS of EAE mice in vivo was not due to a defect in proliferation under Th17 conditions or in a recall response to MOG Ag, respectively. In fact, the trend for increased MOGinduced proliferation in spleen cells from RGC-32-/- EAE mice is consistent with our previous reports of increased proliferation of $\mathrm{RGC}-32^{-/-} \mathrm{CD} 4^{+}$cells under $\mathrm{Th} 0$ conditions. In contrast to the previously reported increase in IL-2 production under Th0 conditions, we 
did not find an enhanced IL-2 production in RGC-32-deficient CD4 ${ }^{+} \mathrm{T}$ cells under Th17 conditions.

Th17 differentiation requires the activation of a multifactorial transcriptional complex (38, $39,45)$. The transcription factors IRF4 and BATF contribute to the initial chromatin accessibility and with STAT3 initiate the Th17 transcriptional program $(38,46)$. The master transcription factor ROR $\delta$ t then drives the expression of key Th17 genes and modulates the expression of other genes activated by the initiator transcription factors (47). The impaired IL-17 differentiation in RGC-32 $2^{-/} \mathrm{CD} 4^{+} \mathrm{T}$ cells was associated with decreased mRNA expression of IRF4, BATF, and Rorc in the presence of similar STAT3 phosphorylation. Whereas STAT3 is essential for ROR $\delta$ t expression during Th17 differentiation (48-51), prior reports have demonstrated that IRF4 deficiency can be associated with a decrease in IL-6induced ROR $\delta$ t expression despite similar STAT3 phosphorylation (46). Further studies are required to assess how RGC-32 promotes the expression of RORSt, IRF4, and BATF. Nevertheless, the effect of RGC-23 deletion on these transcription factors suggests that RGC-32 is an upstream mediator in the molecular cascade that contributes to Th17 differentiation.

RGC-32 is known to interact with SMAD2 and SMAD3 in human renal proximal tubular cells and fibroblasts and acts as a transcriptional coactivator to enhance SMAD mediated epithelial- mesenchymal transition and fibroblast activation $(7,10)$. Our results showed more sustained SMAD2 phosphorylation in WT CD4 ${ }^{+}$T cells compared with RGC-32-/$\mathrm{CD}^{+} \mathrm{T}$ cells. These data are in agreement with reports suggesting that SMAD2 plays a positive and nonredundant role in Th17 differentiation and suggest that RGC-32 is a downstream partner of the TGF- $\beta$ signaling pathway in Th17 differentiation $(52,53)$.

Previous reports by our group showing increased levels of RGC-32 transcripts in the PBMCs of patients with stable relapsing/ remitting MS and expression of RGC-32 protein in T cells, macrophages, and astrocytes in the brain of MS patients suggest a complex role for RGC-32 in the pathogenesis of MS (5). The attenuated EAE phenotype and decreased proportion of IL-17- producing $\mathrm{CD}^{+}{ }^{+} \mathrm{T}$ cells in the CNS of RGC-32 ${ }^{-/-}$mice was reversed by transfer of WT CD4 ${ }^{+} \mathrm{T}$ cells, suggesting that RGC-32 promotes EAE through a T cell-mediated mechanism. Expression of RGC-32 in astrocytes could also play a role in disease progression. RGC-32 blockade in astrocytes using small interfering RNA inhibited TGF- $\beta$ induced production of procollagen I, fibronectin, and the upregulation of the reactive astrocyte marker a-smooth muscle actin $(5,54)$, suggesting a possible deleterious role for RGC-32 in MS through the formation of glial scars that deter the remyelination and axonal regeneration process (55).

In conclusion, we uncover a new, proinflammatory role exerted by RGC-32 through its ability to promote Th17 immune responses in vitro and in the EAE model in vivo and suggest that RGC-32 inhibition is a potential therapeutic strategy in MS and other Th17 cell-mediated diseases. 


\section{Supplementary Material}

Refer to Web version on PubMed Central for supplementary material.

\section{Acknowledgments}

We thank Dr. Kamal Moudgil (University of Maryland School of Medicine) for helpful advice and constructive discussions and Bodhraj Acharya for technical assistance.

\section{Abbreviations:}

$\begin{array}{ll}\text { BATF } & \text { B cell activating transcription factor } \\ \text { EAE } & \text { experimental autoimmune encephalomyelitis } \\ \text { IRF } & \text { IFN regulatory factor } \\ \text { iTreg } & \text { induced Treg } \\ \text { MOG } & \text { myelin oligodendrocyte glycoprotein } \\ \text { MS } & \text { multiple sclerosis } \\ \text { RGC } & \text { response gene to complement } \\ \text { ROR } & \text { retinoic acid-related orphan receptor } \\ \text { Treg } & \text { regulatory T cell } \\ \text { WT } & \text { wild-type }\end{array}$

\section{References}

1. Fosbrink M, Cudrici C, Tegla CA, Soloviova K, Ito T, Vlaicu S, Rus V,Niculescu F, and Rus H. 2009 Response gene to complement 32 is required for C5b-9 induced cell cycle activation in endothelial cells. Exp. Mol. Pathol 86: 87-94. [PubMed: 19162005]

2. Park ES, Choi S, Muse KN, Curry TE, Jr., and Jo M. 2008 Response geneto complement 32 expression is induced by the luteinizing hormone (LH) surge and regulated by LH-induced mediators in the rodent ovary. Endocrinology 149: 3025-3036. [PubMed: 18308847]

3. Tang R, Zhang G, and Chen SY. 2014 Response gene to complement 32 protein promotes macrophage phagocytosis via activation of protein kinase C pathway. J. Biol. Chem 289: 2271522722. [PubMed: 24973210]

4. Badea TC, Niculescu FI, Soane L, Shin ML, and Rus H. 1998 Molecularcloning and characterization of RGC-32, a novel gene induced by complement activation in oligodendrocytes. J. Biol. Chem 273: 26977-26981. [PubMed: 9756947]

5. Tegla CA, Cudrici CD, Azimzadeh P, Singh AK, Trippe R, III, Khan A,Chen H, Andrian-Albescu M, Royal W, III, Bever C, et al. 2013 Dual role of response gene to complement-32 in multiple sclerosis. Exp. Mol. Pathol 94: 17-28. [PubMed: 23000427]

6. Badea T, Niculescu F, Soane L, Fosbrink M, Sorana H, Rus V, Shin ML, and Rus H. 2002 RGC-32 increases p34 ${ }^{\mathrm{CDC} 2}$ kinase activity and entry of aortic smooth muscle cells into S-phase. J. Biol. Chem 277: 502-508. [PubMed: 11687586]

7. Guo X, Jose PA, and Chen SY. 2011 Response gene to complement 32 interacts with Smad3 to promote epithelial-mesenchymal transition of human renal tubular cells. Am. J. Physiol. Cell Physiol 300: C1415-C1421. [PubMed: 21307346] 
8. Vlaicu SI, Tatomir A, Boodhoo D, Ito T, Fosbrink M, Cudrici C,Mekala AP, Ciriello J, Cris s an D, Boţan E, et al. 2016 RGC-32 is expressed in the human atherosclerotic arterial wall: role in C5b-9induced cell proliferation and migration. Exp. Mol. Pathol 101: 221-230. [PubMed: 27619159]

9. Saigusa K, Imoto I, Tanikawa C, Aoyagi M, Ohno K, Nakamura Y, andInazawa J. 2007 RGC32, a novel p53-inducible gene, is located on centrosomes during mitosis and results in G2/M arrest. Oncogene 26: 1110-1121. [PubMed: 17146433]

10. Li Z, Xie WB, Escano CS, Asico LD, Xie Q, Jose PA, and Chen SY.2011 Response gene to complement 32 is essential for fibroblast activation in renal fibrosis. J. Biol. Chem 286: 4132341330. [PubMed: 21990365]

11. Huang WY, Li ZG, Rus H, Wang X, Jose PA, and Chen SY. 2009 RGC32 mediates transforming growth factor-b-induced epithelial-mesenchymal transition in human renal proximal tubular cells. J. Biol. Chem 284: 9426-9432. [PubMed: 19158077]

12. Tegla CA, Cudrici CD, Nguyen V, Danoff J, Kruszewski AM,Boodhoo D, Mekala AP, Vlaicu SI, Chen C, Rus V, et al. 2015 RGC-32 is a novel regulator of the T-lymphocyte cell cycle. Exp. Mol. Pathol 98: 328-337. [PubMed: 25770350]

13. Schlick SN, Wood CD, Gunnell A, Webb HM, Khasnis S, Schepers A, and West MJ. 2011 Upregulation of the cell-cycle regulator RGC-32 in Epstein-Barr virus-immortalized cells. PLoS One 6: e28638. [PubMed: 22163048]

14. Vlaicu SI, Tegla CA, Cudrici CD, Fosbrink M, Nguyen V, Azimzadeh P,Rus V, Chen H, Mircea PA, Shamsuddin A, and Rus H. 2010 Epigenetic modifications induced by RGC-32 in colon cancer. Exp. Mol. Pathol 88: 67-76. [PubMed: 19883641]

15. Patel DD, and Kuchroo VK. 2015 Th17 cell pathway in human immunity:lessons from genetics and therapeutic interventions. Immunity 43: 1040-1051. [PubMed: 26682981]

16. Ho“ltta V, Klemetti P, Sipponen T, Westerholm-Ormio M, Kociubinski G, Salo H, Ra“sa“nen L, Kolho KL, Fa"rkkila“ M, Savilahti E, and Vaarala O. 2008 IL-23/IL-17 immunity as a hallmark of Crohn's disease. Inflamm. Bowel Dis 14: 1175-1184. [PubMed: 18512248]

17. Mizui M, Koga T, Lieberman LA, Beltran J, Yoshida N, Johnson MC,Tisch R, and Tsokos GC. 2014 IL-2 protects lupus-prone mice from multiple end-organ damage by limiting CD42CD82 IL-17-producing T cells. J. Immunol 193: 2168-2177. [PubMed: 25063876]

18. Koga T, Hedrich CM, Mizui M, Yoshida N, Otomo K, Lieberman LA,Rauen T, Crispı́n JC, and Tsokos GC. 2014 CaMK4-dependent activation of AKT/mTOR and CREM-a underlies autoimmunity-associated Th17 imbalance. J. Clin. Invest 124: 2234-2245. [PubMed: 24667640]

19. Lock C, Hermans G, Pedotti R, Brendolan A, Schadt E, Garren H,Langer-Gould A, Strober S, Cannella B, Allard J, et al. 2002 Gene-microarray analysis of multiple sclerosis lesions yields new targets validated in autoimmune encephalomyelitis. Nat. Med 8: 500-508. [PubMed: 11984595]

20. Kebir H, Kreymborg K, Ifergan I, Dodelet-Devillers A, Cayrol R, Bernard M, Giuliani F, Arbour N, Becher B, and Prat A. 2007 Human TH17 lymphocytes promote blood-brain barrier disruption and central nervous system inflammation. Nat. Med 13: 1173-1175. [PubMed: 17828272]

21. Jandus C, Bioley G, Rivals JP, Dudler J, Speiser D, and Romero P. 2008 Increased numbers of circulating polyfunctional Th17 memory cells in patients with seronegative spondylarthritides. Arthritis Rheum 58: 2307-2317. [PubMed: 18668556]

22. Nguyen V, Luzina I, Rus H, Tegla C, Chen C, and Rus V. 2012 IL-21 promotes lupus-like disease in chronic graft-versus-host disease through both CD4 T cell- and B cell-intrinsic mechanisms. J. Immunol 189: 1081-1093. [PubMed: 22723520]

23. Nguyen V, Rus H, Chen C, and Rus V. 2016 CTL-promoting effects of IL-21 counteract murine lupus in the parent $\rightarrow \mathrm{F} 1$ graft-versus-host disease model. J. Immunol 196: 1529-1540. [PubMed: 26792801]

24. Rus V, Nguyen V, Puliaev R, Puliaeva I, Zernetkina V, Luzina I,Papadimitriou JC, and Via CS. 2007 T cell TRAIL promotes murine lupus by sustaining effector CD4 Th cell numbers and by inhibiting CD8 CTL activity. J. Immunol 178: 3962-3972. [PubMed: 17339497]

25. Nguyen V, Cudrici C, Zernetkina V, Niculescu F, Rus H, Drachenberg C,and Rus V. 2009 TRAIL, DR4 and DR5 are upregulated in kidneys from patients with lupus nephritis and exert proliferative and proinflammatory effects. Clin. Immunol 132: 32-42. [PubMed: 19349211] 
26. Vlaicu SI, Cudrici C, Ito T, Fosbrink M, Tegla CA, Rus V, Mircea PA, and Rus H. 2008 Role of response gene to complement 32 in diseases. Arch. Immunol. Ther. Exp. (Warsz.) 56: 115-122.

27. Niculescu T, Weerth S, Niculescu F, Cudrici C, Rus V, Raine CS,Shin ML, and Rus H. 2004 Effects of complement C5 on apoptosis in experimental autoimmune encephalomyelitis. J. Immunol 172: 5702-5706. [PubMed: 15100315]

28. Chung Y, Chang SH, Martinez GJ, Yang XO, Nurieva R, Kang HS,Ma L, Watowich SS, Jetten AM, Tian Q, and Dong C. 2009 Critical regulation of early Th17 cell differentiation by interleukin-1 signaling. Immunity 30: 576-587. [PubMed: 19362022]

29. Cudrici C, Ito T, Zafranskaia E, Weerth S, Rus V, Chen H, Niculescu F,Soloviova K, Tegla C, Gherman A, et al. 2008 Complement C5 regulates the expression of insulin-like growth factor binding proteins in chronic experimental allergic encephalomyelitis. J. Neuroimmunol 203: 94103. [PubMed: 18692252]

30. Mangan PR, Harrington LE, O' Quinn DB, Helms WS, Bullard DC,Elson CO, Hatton RD, Wahl SM, Schoeb TR, and Weaver CT. 2006 Transforming growth factor-b induces development of the TH17 lineage. Nature 441: 231-234. [PubMed: 16648837]

31. Esplugues E, Huber S, Gagliani N, Hauser AE, Town T, Wan YY,O’Connor W, Jr., Rongvaux A, Van Rooijen N, Haberman AM, et al. 2011 Control of $\mathrm{T}_{\mathrm{H}} 17$ cells occurs in the small intestine. Nature 475: 514-518. [PubMed: 21765430]

32. Francisco LM, Sage PT, and Sharpe AH. 2010 The PD-1 pathway intolerance and autoimmunity. Immunol. Rev 236: 219-242. [PubMed: 20636820]

33. Ronchetti S, Ricci E, Petrillo MG, Cari L, Migliorati G, Nocentini G, and Riccardi C 2015 Glucocorticoid-induced tumour necrosis factor receptorrelated protein: a key marker of functional regulatory T cells. J. Immunol. Res 2015: 171520. [PubMed: 25961057]

34. Takahashi T, Tagami T, Yamazaki S, Uede T, Shimizu J, Sakaguchi N,Mak TW, and Sakaguchi S. 2000 Immunologic self-tolerance maintained by CD25+CD4+ regulatory T cells constitutively expressing cytotoxic T lymphocyte-associated antigen 4. J. Exp. Med 192: 303-310. [PubMed: 10899917]

35. Laurence A, Tato CM, Davidson TS, Kanno Y, Chen Z, Yao Z, Blank RB,Meylan F, Siegel R, Hennighausen L, et al. 2007 Interleukin-2 signaling via STAT5 constrains T helper 17 cell generation. Immunity 26: 371-381. [PubMed: 17363300]

36. Schmitt N, and Ueno H. 2015 Regulation of human helper T cell subsetdifferentiation by cytokines. Curr. Opin. Immunol 34: 130-136. [PubMed: 25879814]

37. Yang XP, Ghoreschi K, Steward-Tharp SM, Rodriguez-Canales J, Zhu J,Grainger JR, Hirahara K, Sun HW, Wei L, Vahedi G, et al. 2011 Opposing regulation of the locus encoding IL-17 through direct, reciprocal actions of STAT3 and STAT5. Nat. Immunol 12: 247-254. [PubMed: 21278738]

38. Ciofani M, Madar A, Galan C, Sellars M, Mace K, Pauli F, Agarwal A,Huang W, Parkhurst CN, Muratet M, et al. 2012 A validated regulatory network for Th17 cell specification. Cell 151: 289303. [PubMed: 23021777]

39. Yosef N, Shalek AK, Gaublomme JT, Jin H, Lee Y, Awasthi A, Wu C,Karwacz K, Xiao S, Jorgolli M, et al. 2013 Dynamic regulatory network controlling TH17 cell differentiation. Nature 496: 461-468. [PubMed: 23467089]

40. Schraml BU, Hildner K, Ise W, Lee WL, Smith WA, Solomon B,Sahota G, Sim J, Mukasa R, Cemerski S, et al. 2009 The AP-1 transcription factor Batf controls TH17 differentiation. Nature 460: 405-409. [PubMed: 19578362]

41. Nurieva R, Yang XO, Martinez G, Zhang Y, Panopoulos AD, Ma L,Schluns K, Tian Q, Watowich SS, Jetten AM, and Dong C. 2007 Essential autocrine regulation by IL-21 in the generation of inflammatory T cells. Nature 448: 480-483. [PubMed: 17581589]

42. Langrish CL, Chen Y, Blumenschein WM, Mattson J, Basham B,Sedgwick JD, McClanahan T, Kastelein RA, and Cua DJ. 2005 IL-23 drives a pathogenic T cell population that induces autoimmune inflammation. J. Exp. Med 201: 233-240. [PubMed: 15657292]

43. Codarri L, Gy€ulve'szi G, Tosevski V, Hesske L, Fontana A, Magnenat L, Suter T, and Becher B. 2011 RORSt drives production of the cytokine GM-CSF in helper T cells, which is essential for the effector phase of autoimmune neuroinflammation. Nat. Immunol 12: 560-567. [PubMed: 21516112] 
44. Cravens PD, Hussain RZ, Zacharias TE, Ben LH, Herndon E, Vinnakota R, Lambracht-Washington D, Nessler S, Zamvil SS, Eagar TN, and St O€uve. 2011 Lymph node-derived donor encephalitogenic CD4 ${ }^{+} \mathrm{T}$ cells in C57BL/6 mice adoptive transfer experimental autoimmune encephalomyelitis highly express GM-CSF and T-bet. J. Neuroinflammation 8: 73. [PubMed: 21702922]

45. Malhotra N, and Kang J. 2013 SMAD regulatory networks construct a balanced immune system. Immunology 139: 1-10. [PubMed: 23347175]

46. Br€ustle A, Heink S, Huber M, Rosenpla“nter C, Stadelmann C, Yu P, Arpaia E, Mak TW, Kamradt T, and Lohoff M. 2007 The development of inflammatory $\mathrm{T}_{\mathrm{H}^{-}} 17$ cells requires interferon-regulatory factor 4. Nat. Immunol 8: 958-966. [PubMed: 17676043]

47. Ivanov II, McKenzie BS, Zhou L, Tadokoro CE, Lepelley A, Lafaille JJ,Cua DJ, and Littman DR. 2006 The orphan nuclear receptor ROR $\delta$ t directs the differentiation program of proinflammatory IL-17 ${ }^{+}$T helper cells. Cell 126: 1121-1133. [PubMed: 16990136]

48. Yang XO, Panopoulos AD, Nurieva R, Chang SH, Wang D, Watowich SS, and Dong C. 2007 STAT3 regulates cytokine-mediated generation of inflammatory helper T cells. J. Biol. Chem 282: 9358-9363. [PubMed: 17277312]

49. Zhou L, Ivanov II, Spolski R, Min R, Shenderov K, Egawa T, Levy DE,Leonard WJ, and Littman DR. 2007 IL-6 programs TH-17 cell differentiation by promoting sequential engagement of the IL-21 and IL-23 pathways. Nat. Immunol 8: 967-974. [PubMed: 17581537]

50. Tanaka S, Suto A, Iwamoto T, Kashiwakuma D, Kagami S, Suzuki K,Takatori H, Tamachi T, Hirose K, Onodera A, et al. 2014 Sox 5 and c-Maf cooperatively induce Th17 cell differentiation via RORSt induction as downstream targets of Stat3. J. Exp. Med 211: 1857-1874. [PubMed: 25073789]

51. Mathur AN, Chang HC, Zisoulis DG, Stritesky GL, Yu Q,O’Malley JT, Kapur R, Levy DE, Kansas GS, and Kaplan MH. 2007 Stat3 and Stat4 direct development of IL-17-secreting Th cells. J. Immunol 178: 4901-4907. [PubMed: 17404271]

52. Malhotra N, Robertson E, and Kang J. 2010 SMAD2 is essential for TGFbmediated Th17 cell generation. J. Biol. Chem 285: 29044-29048. [PubMed: 20656683]

53. Martinez GJ, Zhang Z, Reynolds JM, Tanaka S, Chung Y, Liu T,Robertson E, Lin X, Feng XH, and Dong C. 2010 Smad2 positively regulates the generation of Th17 cells. J. Biol. Chem 285: 2903929043. [PubMed: 20667820]

54. Tatomir A, Tegla C, Cudrici C, Boodhoo D, Martin A, Mekala AP, Rus V,Badea T, and Rus H 2016 RGC-32 regulates TGF- $\beta$ extracellular matrix production in multiple sclerosis. J Immunol 196 (Suppl.): 189.7.

55. Brosnan CF, and Raine CS. 2013 The astrocyte in multiple sclerosisrevisited. Glia 61: 453-465. [PubMed: 23322421] 


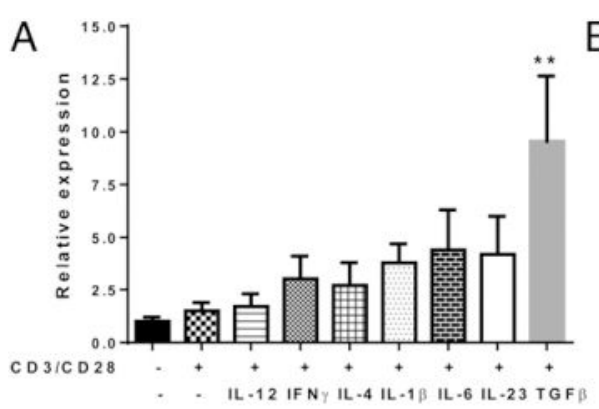

D

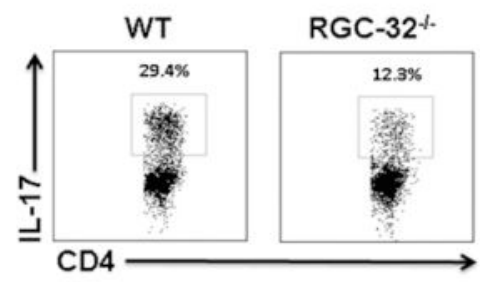

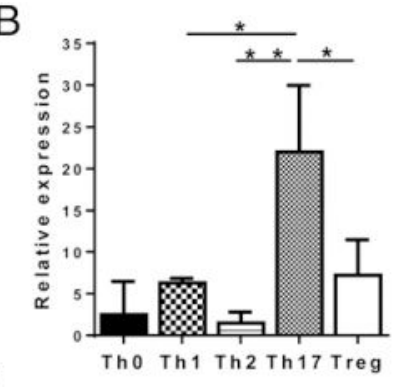

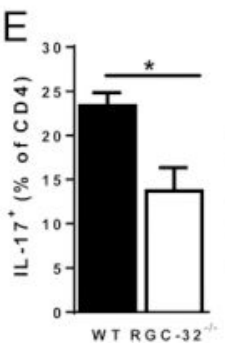

$\mathrm{F}$

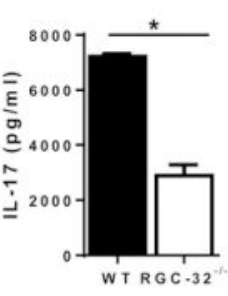

C

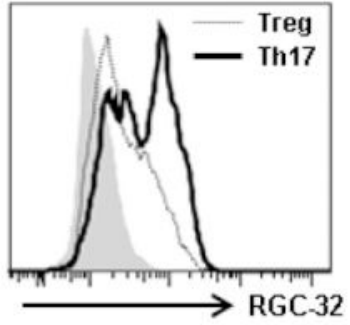

G

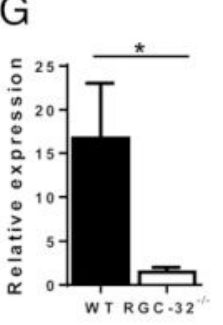

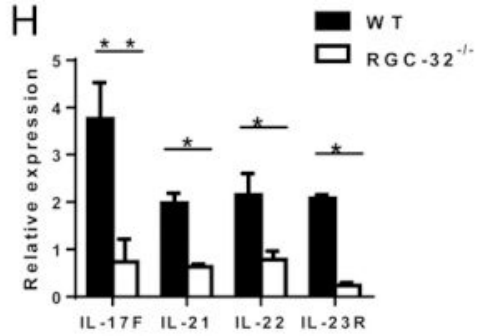

FIGURE -1.

RGC-32 is preferentially induced in Th17 cells and promotes their differentiation. (A)

Quantitative RT-PCR for RGC-32 in naive CD4 ${ }^{+} \mathrm{T}$ cells from spleens of WT mice stimulated for $48 \mathrm{~h}$ with anti-CD3 and anti-CD28 in the presence or absence of indicated cytokines and in (B) Th0, Th1, Th2, Th17, or Treg polarizing conditions (**p, 0.01; mean 6 SEM; $\mathrm{n}=3-4$ mice per group). (C) Representative histogram of RGC-32 intracellular staining in $\mathrm{CD}^{+} \mathrm{T}$ cells cultured under Th17 and Treg conditions. Gray histogram represents background staining in RGC- $32^{-/-}$CD $4^{+} \mathrm{T}$ cells. (D and E) Naive $\mathrm{CD} 4^{+} \mathrm{T}$ cells were cultured for $72 \mathrm{~h}$ in Th17 conditions and intracellular expression of IL-17A was assessed by flow cytometry. A representative profile is shown. Plots were gated on viable singlet $\mathrm{CD} 4^{+}$events. (F) ELISA for IL-17A determined in supernatants. (G) Real-time PCR for IL-17A. (H) Quantitative RT-PCR for Th17 signature genes IL-17F, IL-21, IL-22, and IL-23R. (*p, 0.05, **p, 0.01, mean 6 SEM). Data are representative of more than three independent experiments ( $n=3-4$ mice per group). 

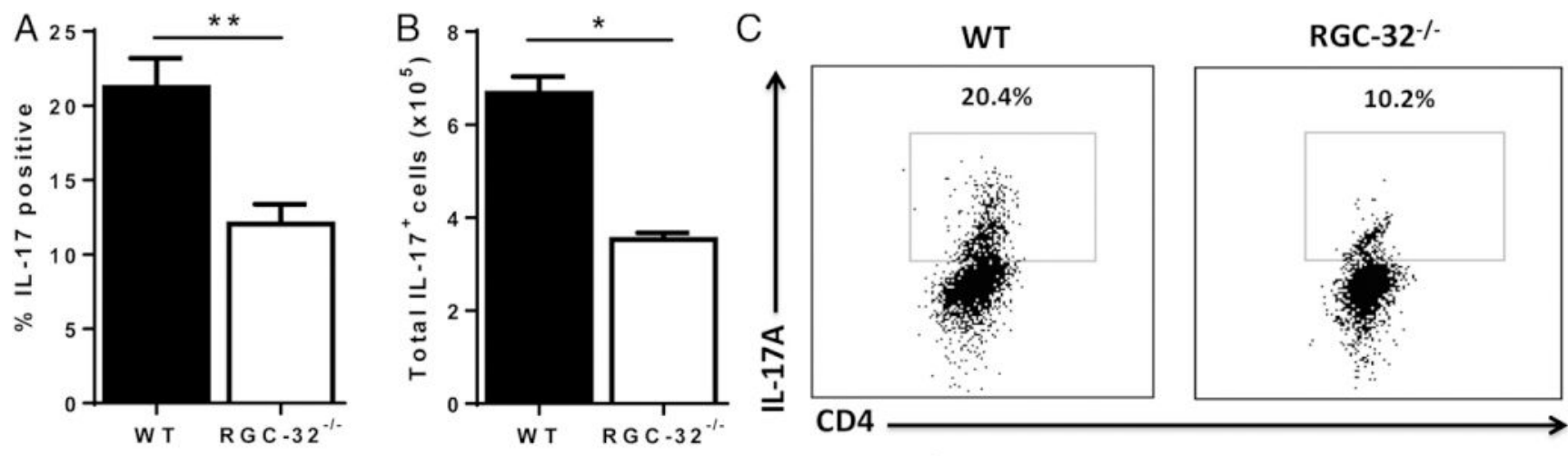

FIGURE 2.

Decreased $\mathrm{CD} 4{ }^{+} \mathrm{IL}-17^{+} \mathrm{T}$ cells in lamina propria lymphocytes of RGC-32-/- mice. Freshly isolated lamina propria lymphocytes from WT and RGC-32-/- mice were stimulated in vitro with PMA/ionomycin for $4 \mathrm{~h}$ before intracellular cytokine staining for IL-17A. (A and B) Percentage and total number of IL-17A-expressing CD4 ${ }^{+} \mathrm{T}$ cells. (C) A representative profile is shown. Plots were gated on viable singlet $\mathrm{CD} 4{ }^{+}$events $(* \mathrm{p}, 0.05$, **p, 0.01, mean 6 SEM. Data are representative of three independent experiments; $n=2-3$ mice per group). 
A

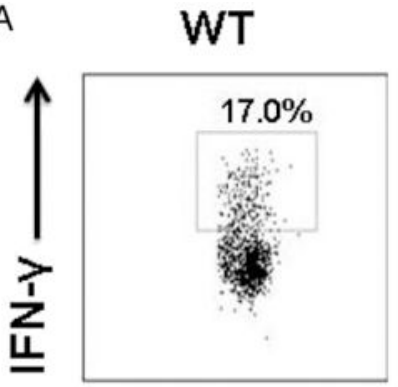

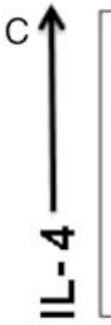

CD4
RGC-32
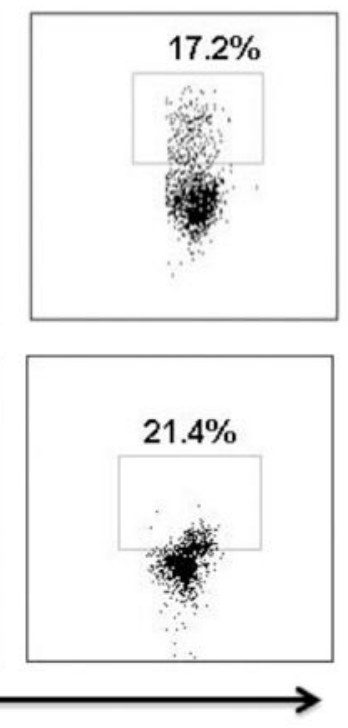

E

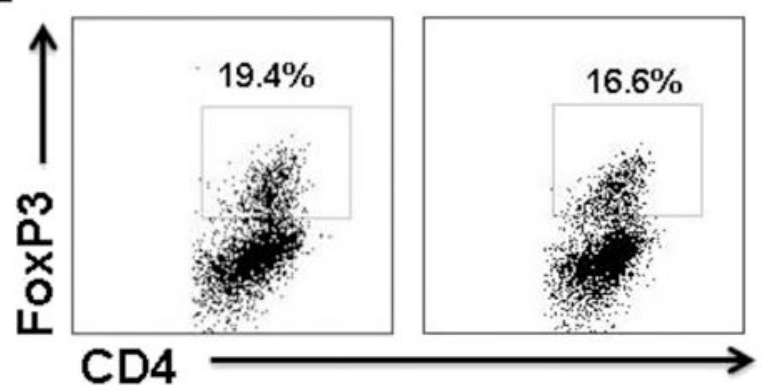

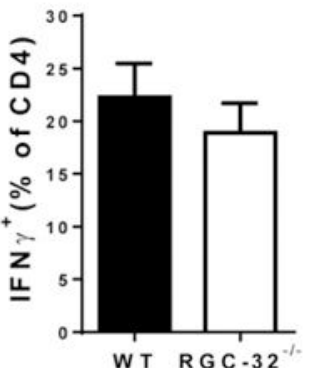
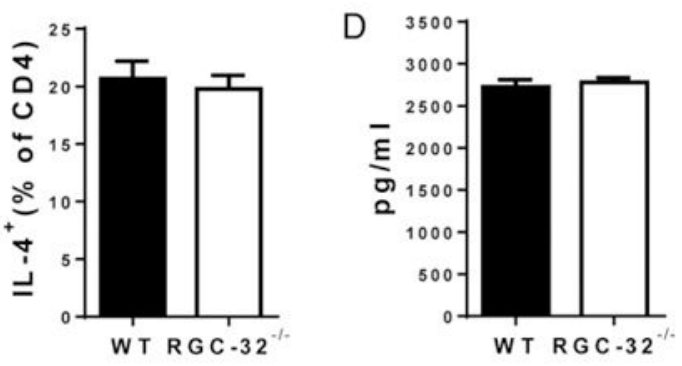

B

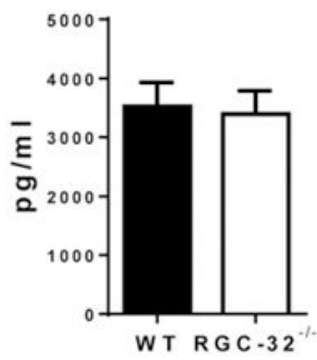

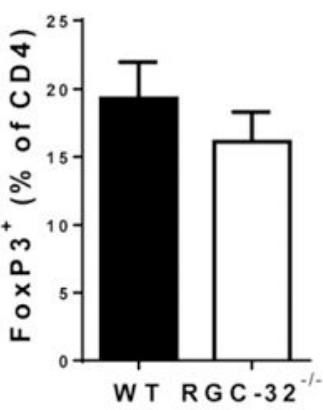

$\mathrm{F}$

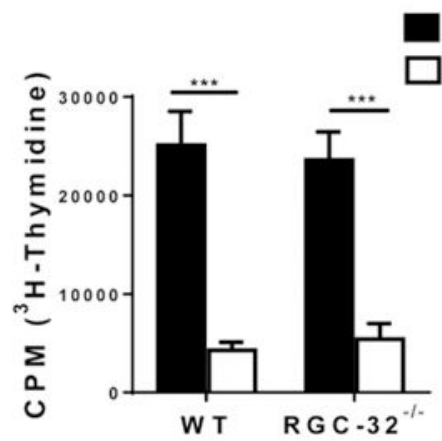

T responder

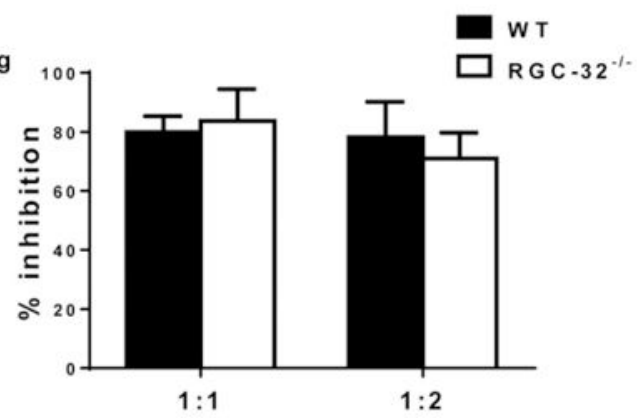

FIGURE 3.

RGC-32- $2^{--} \mathrm{CD} 4{ }^{+} \mathrm{T}$ cells polarize normally to Th1, Th2, and Treg lineages. Naive CD4 ${ }^{+} \mathrm{T}$ cells were skewed in vitro under Th1, Th2, and Treg conditions. (A) Intracellular expression of IFN- $\gamma$ was assessed by flow cytometry. (B) ELISA for IFN- $\gamma$ determined in supernatants. (C) Intracellular expression of IL-4 was assessed by flow cytometry. (D) ELISA for IL-4 determined in supernatants. (E) Foxp3 expression was determined by intracellular staining. (F) In vitro suppression assay of purified $\mathrm{CD} 4^{+} \mathrm{CD} 25^{2} \mathrm{~T}$ responder cells cocultured for $3 \mathrm{~d}$ with in vitro-differentiated, purified $\mathrm{CD} 4^{+} \mathrm{CD} 25^{+}$iTregs from WT or RGC- $32^{-/-}$mice. 
Proliferation was assessed by $\left[{ }^{3} \mathrm{H}\right]$ thymidine incorporation added in the last $18 \mathrm{~h}$ of culture (left panel). Percentage inhibition at 1:1 and 1:2 Treg/T responder ratio is shown in the right panel. ***p, 0.001. Data represent the mean $6 \mathrm{SD}$ and are representative of more than three independent experiments ( $n=3$ mice per group). Representative profiles shown for intracellular IL-4, IFN- $\gamma$, and Foxp3 are gated on viable singlet CD4 ${ }^{+}$events. 

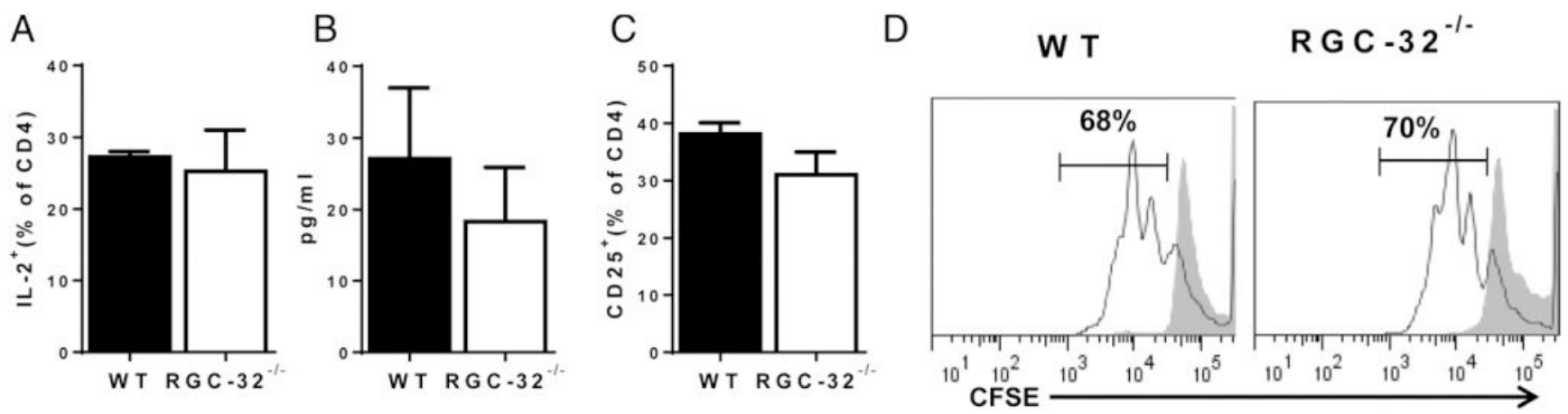

FIGURE 4.

Lack of RGC-32-/- did not affect expression of IL-2/IL-2R or cell division. (A) Naive CD4 ${ }^{+}$ T cells were stimulated under Th17 conditions. After $48 \mathrm{~h}$, IL-2 expression was determined by intracellular staining and (B) ELISA. (C) Percentage of CD $25^{+} \mathrm{CD} 4^{+} \mathrm{T}$ cells. (D) Naive $\mathrm{CD} 4^{+} \mathrm{T}$ cells were stained with CFSE prior to culture under Th17 conditions. CFSE dilution due to cell proliferation was determined by flow cytometry on gated CD $4^{+} \mathrm{IL}-17^{+}$cells. Results are representative of more than three independent experiments ( $n=3$ mice per group). 
A

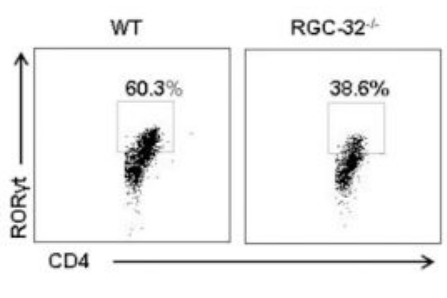

E

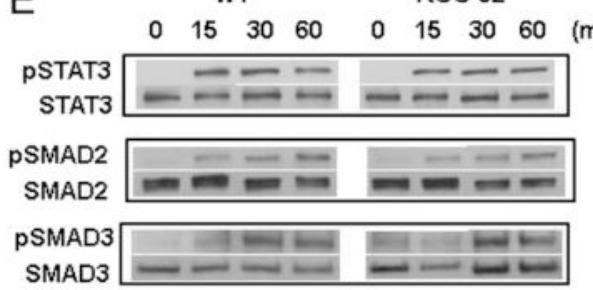

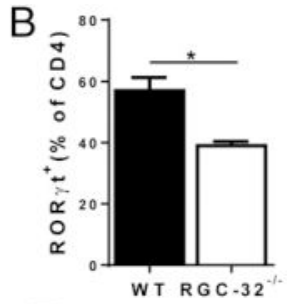

$\mathrm{F}$

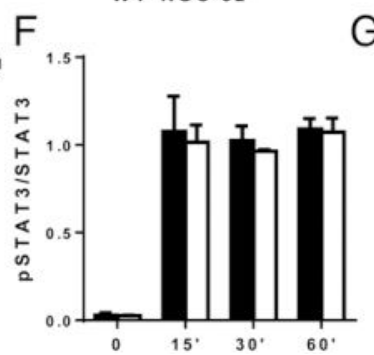

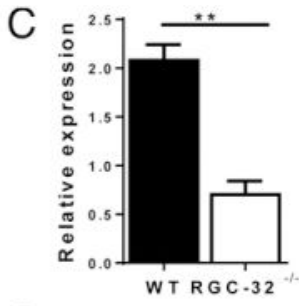

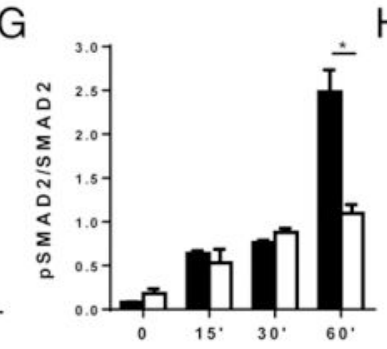

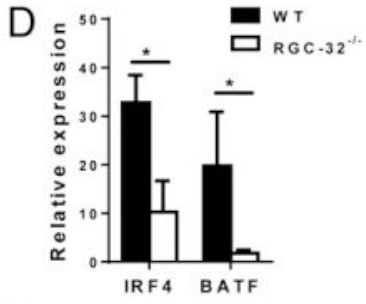

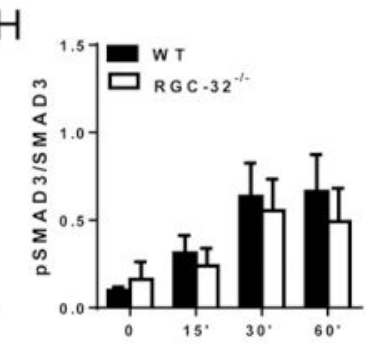

FIGURE 5.

RGC-32 promotes Th17 cell differentiation through TGF- $\beta$-dependent and -independent mechanisms. Freshly isolated naive $\mathrm{CD} 4{ }^{+} \mathrm{T}$ cells were stimulated under Th17 conditions. (A and B) ROR $\delta$ expression was determined by intracellular staining. (C) Quantitative RT-PCR for Rorc. (D) Quantitative RT-PCR for IRF4 and BATF. (E) Western blotting analysis of phospho-STAT3, -SMAD2, and -SMAD3 in unstimulated and Th17 conditions for the indicated times. The graphs in $(\mathbf{F})-(\mathbf{H})$ show cumulative data of densitometry (*p, 0.05, **p, 0.01 , mean 6 SEM). Data are representative of three independent experiments $(n=3$ mice per group) 
A

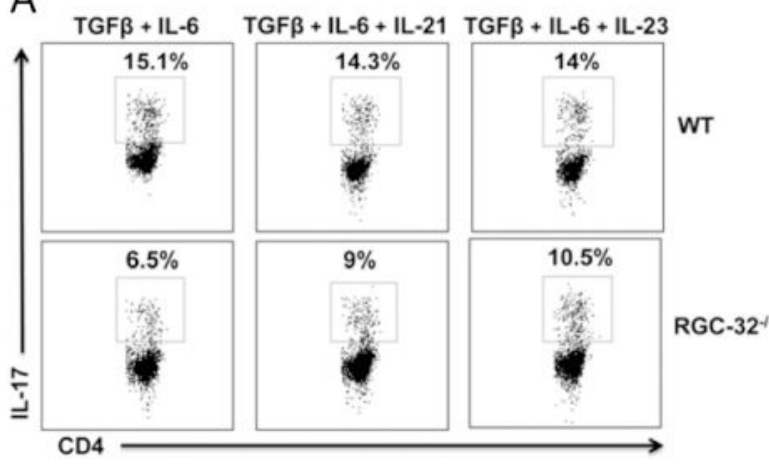

$\mathrm{B}$

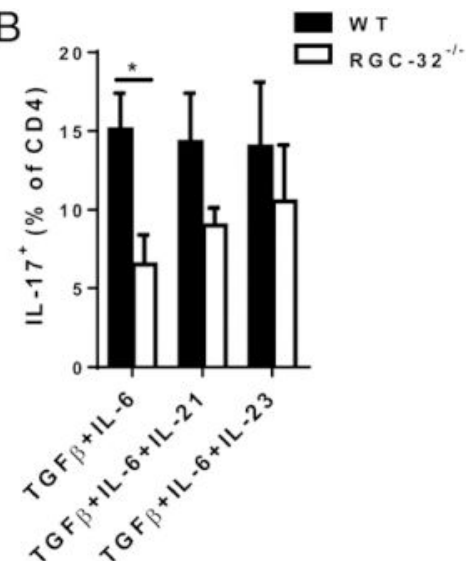

FIGURE 6.

IL-21 and IL-23 do not restore defective IL-17 production in RGC-32-/- CD4 $4^{+} \mathrm{T}$ cells.

Naive $\mathrm{CD} 4^{+} \mathrm{T}$ cells from WT and $\mathrm{RGC} 32^{-/-}$mice were cultured under Th17 conditions and IL-21 or IL-23 was added after $24 \mathrm{~h}$ of culture. (A and B) Intracellular expression of IL-17A was assessed at $72 \mathrm{~h}$ by flow cytometry. A representative profile is shown. Plots were gated on viable singlet $\mathrm{CD} 4^{+}$events $\left({ }^{*} \mathrm{p}<0.05\right.$; mean $6 \mathrm{SEM} ; n=3$ mice per group). 
A

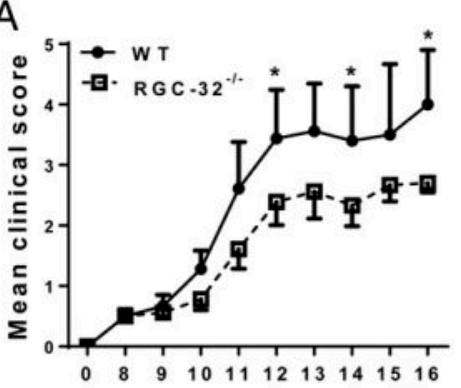

Time after immunization

D

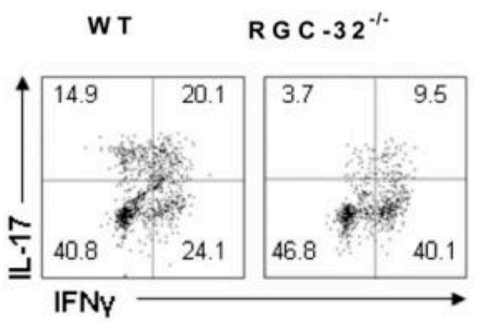

$\mathrm{H}$

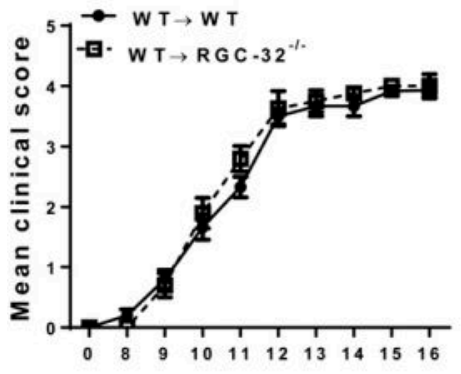

Time after im munization

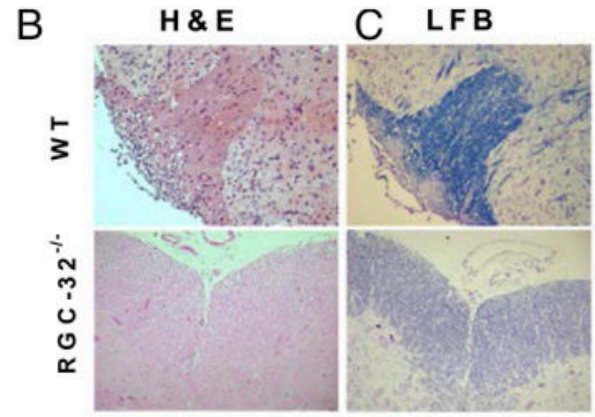

$E$

$\mathrm{F}$
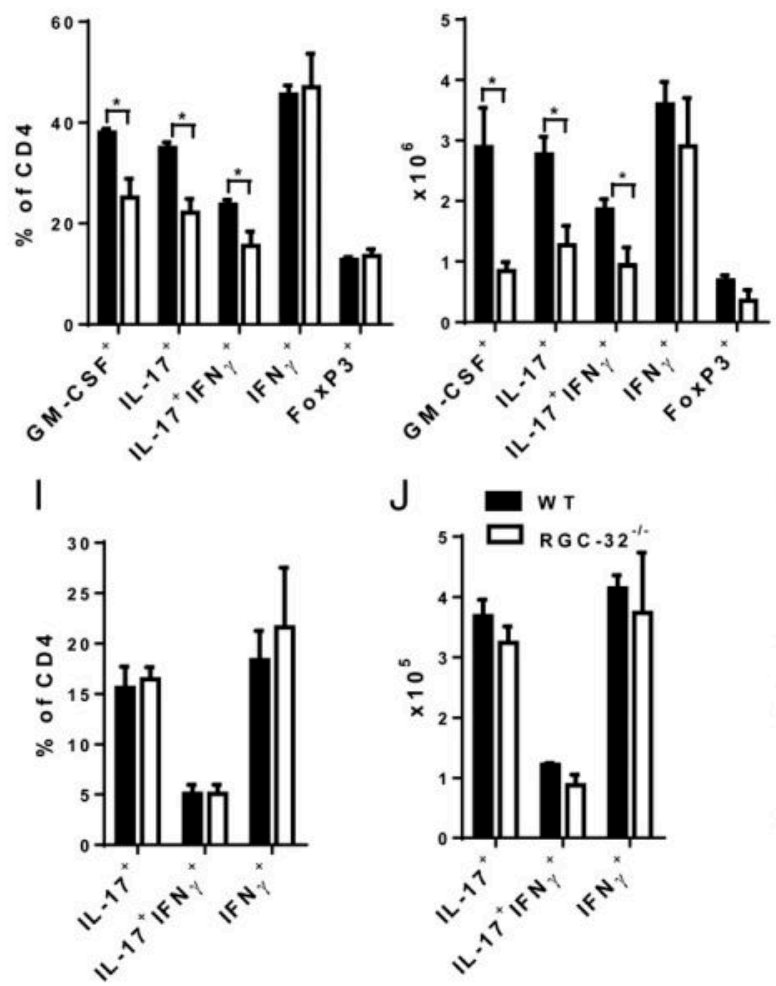

$J$

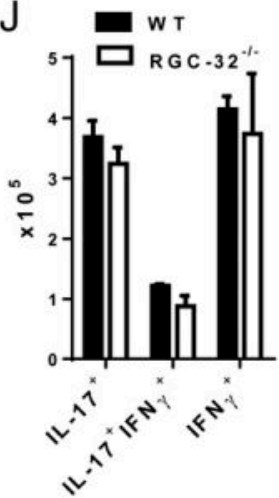

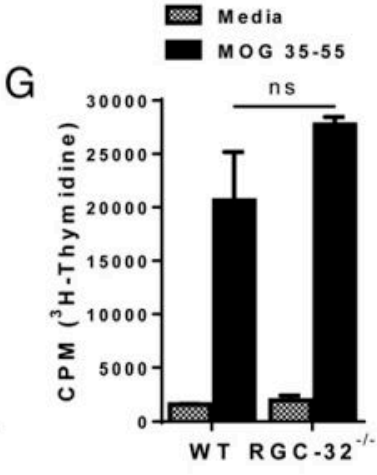

$\mathrm{K}$

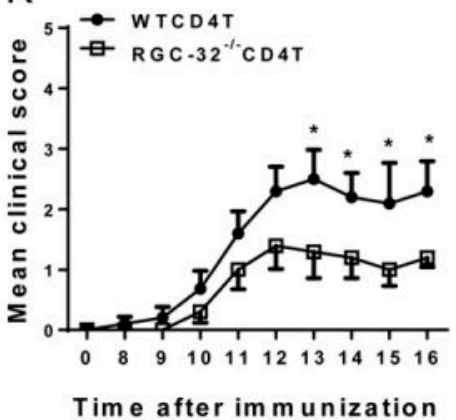

FIGURE 7.

Lack of RGC-32 ameliorates EAE and CNS infiltration. WT $(\mathrm{n}=10)$ and RGC-32-/- $(\mathrm{n}=9)$ mice were immunized with MOG35-55 peptide. (A) Mean clinical EAE scores 6 SEM are shown and are representative of three independent experiments (*p, 0.05). (B and $\mathbf{C}$ ) H\&E and Luxol fast blue (LFB) staining of cervical spinal cords harvested at the peak of disease. Original magnification 3200. (D) Thirteen days after disease induction, CNSinfiltrating lymphocytes were isolated, stimulated with PMA and ionomycin for $4 \mathrm{~h}$, and stained for IL-17A and IFN- $\gamma$. Representative flow cytometric analysis of cytokine profile on gated $\mathrm{CD}^{+} \mathrm{T}$ cells is shown. (E and $\left.\mathbf{F}\right)$ Percentage and total number of GM-CSF${ }^{+}, \mathrm{IL}^{-17^{+}}, \mathrm{IFN}-\gamma$ ${ }^{+}$, and IL- $17^{+} \mathrm{IFN}-\gamma^{+} \mathrm{CD} 4^{+} \mathrm{T}$ cells in the CNS $\left({ }^{*} \mathrm{p}, 0.05\right.$; mean 6 SEM; $\mathrm{n}=3$ mice per group). (G) Splenocytes from MOG-immunized WT and RGC-32-/- mice were cultured in the presence or absence of $\mathrm{MOG}_{35-55}(25 \mu \mathrm{g} / \mathrm{ml})$ for $72 \mathrm{~h}$. Proliferation was determined by [ H]thymidine incorporation. (H) WT CD4 ${ }^{+}$T cells were injected into WT and RGC-32-/mice $5 \mathrm{~d}$ prior to EAE induction. Mean clinical EAE scores 6 SEM are shown. (I and $\mathbf{J})$ 
Percentage and total number of $\mathrm{IL}-17^{+}-$, IFN- $\gamma^{+}$, and IL- $17^{+} \mathrm{IFN}-\gamma^{+}$-expressing $\mathrm{CD} 4^{+} \mathrm{T}$ cells in the CNS. *p, 0.05. Data shown are representative of three independent experiments (K). $\mathrm{CD}^{+} \mathrm{T}$ cells $\left(7 \times 10^{6}\right)$ from WTor RGC-32 $2^{-/-}$mice were injected into RAG1 ${ }^{-1-}$ mice 1 $\mathrm{d}$ prior to EAE induction. Mean clinical EAE scores 6 SEM are shown. *p, 0.05 . 